\title{
Fatty acids in component of milk enhance the expression of the cAMP-response-element-binding-protein-binding protein (CBP)/p300 gene in developing rats
}

\author{
Kazuki Mochizuki ${ }^{1}$, Hiromi Kawai ${ }^{1}$, Hiroko Mochizuki ${ }^{2}$, Masaya Shimada ${ }^{1}$, Sachiko Takase ${ }^{3}$ and \\ Toshinao Goda ${ }^{1}$. \\ ${ }^{1}$ School of Food and Nutritional Sciences, The University of Shizuoka, 52-1 Yada, Shizuoka-shi, Shizuoka 422-8526, Japan \\ ${ }^{2}$ Shizuoka Eiwa Junior College, Shizuoka 422-8005, Japan \\ ${ }^{3}$ Department of Nutrition and Health Sciences, Siebold University of Nagasaki, Nagasaki 851-2195, Japan
}

(Received 14 February 2007 - Revised 9 July 2007 - Accepted 20 July 2007)

Fatty acids in milk are thought to play an important role in intestinal maturation and gene expression in the rat small intestine during the sucklingweaning period. In the present study, we determined the jejunal mRNA level of the cAMP-response-element-binding-protein-binding protein $(\mathrm{CBP}) / \mathrm{p} 300$, which is one of the chromatin remodelling factors and regulates histone acetylation, during the postnatal period in rats. The mRNA level of CBP/p300 was high during the suckling and middle of the weaning period (day 5 to 20) and then declined sharply to a low level at the end of the weaning period and after weaning. In situ hybridisation also showed that CBP/p300 mRNA levels in the villus as well as the basal membrane clearly decreased after weaning. Rat pups at age $17 \mathrm{~d}$, weaned to a high-fat diet, showed higher levels of CBP/ p300 mRNA than those weaned to a low-fat diet. Oral administration of caprylic acid, oleic acid and linoleic acid, which are major fatty acid components in milk, induced jejunal $\mathrm{CBP} / \mathrm{p} 300$ gene expression. The present results suggest that fatty acids in components of milk enhance expression of the $\mathrm{CBP} / \mathrm{p} 300$ genes in the small intestine.

CBP/p300: Fatty acids: Postnatal development: Small intestine

Rat pups ingest fatty acids from milk as major nutrients during the 4-week period following birth which corresponds to the suckling-weaning period. Several studies have shown that fatty acids in milk are important for the development of the small intestine in rat pups during the suckling-weaning period $^{1-4}$. During the transition period from suckling to weaning (13-27 d after birth), the small intestine matures dramatically to its adult form as an adaptation to altered nutrition associated with the change from a diet rich in fat (milk) to one rich in carbohydrate (solid food). The expression of many genes related to digestion or absorption, such as sucrase-isomaltase $(\mathrm{SI})^{5}$, GLUT5 $^{6}$, cellular retinol-binding protein type II (CRBPII) ${ }^{7}$, and liver-type and intestinal-type fatty acid-binding proteins $(\mathrm{L}-\mathrm{FABP} \text { and } \mathrm{I}-\mathrm{FABP})^{8}$, increase during this period. Many studies, including some from our own laboratory, indicate that putative transcriptional factors for these intestinal genes are also up regulated during this period. Our previous research indicates that caudal-related homeobox $2(\mathrm{Cdx}-2)$ and hepatocyte nuclear factor (HNF)-1, which are transcriptional factors for SI gene expression, are highly expressed during the suckling-weaning transitional period $^{9}$. Furthermore, our recent work has demonstrated that thyroid hormone receptor $\alpha-1$, which is a transcriptional factor for GLUT5 gene expression, is highly expressed during this period ${ }^{6}$. Additionally, the gene expression of many other transcriptional factors for intestinal gene expression, such as retinoid $\mathrm{X}$ receptor $\alpha$, retinoic acid receptor (RAR)- $\alpha$ and HNF-4, are highly expressed during this period $^{7}$. Our previous research has shown that some of the nuclear receptors, the PPAR ${ }^{10,11}$, which is activated by fatty acids, as well as its target genes, L-FABP and $\mathrm{I}_{-} \mathrm{FABP}^{7,8,12-16}$, are highly expressed during this period. Additionally, several studies, including some of ours, have demonstrated that PPAR $\alpha$ regulates L-FABP and I-FABP during the weaning period ${ }^{8}$ as well as during adulthood ${ }^{17-20}$. These results suggest that fatty acids in milk may play a role in inducing small-intestinal maturation and differentiation and increasing intestinal gene expression through enhancing gene expression of transcriptional factors. Many recent studies suggest that acute induction of gene expression involved in the cell cycle and differentiation processes occurring during development are regulated not only by transcriptional factors,

Abbreviations: BW, body weight; CBP, cAMP-response-element-binding-protein-binding protein; Cdx-2, caudal-related homeobox 2; CRBPII, cellular retinolbinding protein type II; HNF, hepatocyte nuclear factor; I-FABP, intestinal-type fatty acid-binding protein; L-FABP, liver-type fatty acid-binding protein; RAR, retinoic acid receptor; RXR, retinoid X receptor; SI, sucrase-isomaltase; SSC, sodium chloride and sodium citrate; TR, thyroid hormone receptor; Tris, tri(hydroxymethyl)-aminomethane.

* Corresponding author: Dr Toshinao Goda, fax +81 54264 5565, email gouda@fns1.u-shizuoka-ken.ac.jp 
but also by chromatin remodelling factors such as coactivators, the TRIP/DRIP complex and the SWI/SNF complex ${ }^{21}$. In particular, coactivators, which have histone acetyltransferase activity are thought to play a critical role for transcription regulation, because histone acetylation by histone acetyltransferase including coactivators is the first step for recruiting transcriptional complexes ${ }^{22}$. Recent studies including our own have shown that one of the coactivators, cAMP-response-elementbinding-protein-binding protein $(\mathrm{CBP}) / \mathrm{p} 300$, is expressed in the small intestine and enables transmission of fatty acid signalling via PPAR ${ }^{16,23,24}$. Additionally, it has already been demonstrated that $\mathrm{CBP} / \mathrm{p} 300$ is bound to other transcriptional factors for small-intestinal gene expression such as Cdx- $2^{25}$, HNF$1^{26}, \mathrm{HNF}-4^{27}$, retinoid $\mathrm{X}$ receptor $(\mathrm{RXR})^{28}$ and $\mathrm{RAR}^{28}$ and that it activates their target genes. However, it is not clear whether small-intestinal expression of $\mathrm{CBP} / \mathrm{p} 300$ occurs during the suckling-weaning period and whether its expression is regulated by fatty acids in milk.

In the present study, we focused on changes in expression of the jejunal $\mathrm{CBP} / \mathrm{p} 300$ gene in rats during the sucklingweaning period. The present study indicates that $\mathrm{CBP} / \mathrm{p} 300$ expression, which is associated with postnatal intestinal maturation during the suckling-weaning period, may be regulated by fatty acids in milk.

\section{Materials and methods}

\section{Animals}

Sprague-Dawley suckling rats (Japan SLC, Hamamatsu, Japan) were kept with their mothers, and both mothers and pups were given free access to a standard laboratory chow diet (MF; Oriental Yeast, Tokyo, Japan) throughout the experimental period. To examine the effect of time post-partum on gene expression, we chose the following sampling times: samples collected at $5 \mathrm{~d}$ post-partum represented the suckling period; samples collected at 13, 20 and $27 \mathrm{~d}$ marked the start, middle and end of weaning, respectively; samples collected at $42 \mathrm{~d}$ represented the period after weaning. Rat pups were killed by decapitation, without prior fasting, between 14.30 and 15.00 hours at the ages of 5, 13, 20, 27 and $42 \mathrm{~d}$. To assess the effect of dietary fat during the postnatal stage on intestinal gene expression, in a further experiment, rat pups were removed from their mothers at age $17 \mathrm{~d}$, and they then received free access to either a low-fat diet containing $2.4 \%(\mathrm{w} / \mathrm{w})$ maize oil (essentially TAG, consisting of glycerol esterified to the fatty acids, mainly oleic acid and linoleic acid in maize oil), or a high-fat diet containing $24.7 \%(\mathrm{w} / \mathrm{w})$ maize oil ${ }^{29}$. They were killed at the ages of 21 and $28 \mathrm{~d}$ without prior fasting. In a further experiment, weanling rats were orally administered with $1 \mathrm{ml} / \mathrm{kg}$ body weight (BW) of $20 \%$ glycerol without fatty acids (control), or with $180 \mu \mathrm{mol} / \mathrm{kg} \mathrm{BW}$ of various fatty acids (caprylic acid $(25.96 \mathrm{mg} / \mathrm{kg} \mathrm{BW})$, oleic acid (50.84 mg/kg BW), linoleic acid $(50.48 \mathrm{mg} / \mathrm{kg} \mathrm{BW})$ and arachidonic acid $(54.80 \mathrm{mg} / \mathrm{kg}$ $\mathrm{BW})$ ) once per $\mathrm{d}$ for four consecutive days starting at age $27 \mathrm{~d}$ (between 09.00 and 09.30 hours). These rats were killed without prior fasting between 14.30 and 15.00 hours at age $30 \mathrm{~d}$. The experimental procedure used in the present study met the guidelines of the Animal Usage Committee of the University of Shizuoka.

\section{Ribonucleic acid analysis}

The entire small intestine was flushed with ice-cold $0.9 \%$ $\mathrm{NaCl}$ solution. The jejuno-ileum extending from the ligament of Treitz to the ileocaecal valve was divided into two equal parts along its length. A portion $(100 \mathrm{mg})$ was excised from the middle of the proximal half of the jejuno-ileum (jejunum) and immediately used for RNA extraction. Total RNA was extracted by the acidified guanidinium thiocyanate method as described by Chomczynski \& Sacchi ${ }^{30}$. Northern blot analysis of $\mathrm{CBP} / \mathrm{p} 300$ and $18 \mathrm{~S}$ rRNA was performed using ${ }^{32} \mathrm{P}$-labelled cDNA probes as described previously ${ }^{16,29}$. The probe for $\mathrm{CBP} / \mathrm{p} 300$ in the present study was the rat p300 probe which detects both CBP and p300 signals ${ }^{16}$. The specific mRNA signals from Northern blots were quantified using an image analyser (BAS 2000; Fuji Film, Tokyo, Japan) for Northern blot analysis, and the signals were standardised to the $18 \mathrm{~S}$ rRNA signal.

\section{In situ hybridisation}

The cRNA probe of rat CBP/p300 for in situ hybridisation was prepared using rat p300 $\mathrm{cDNA}^{16}$ as a template. Antisense and sense riboprobes were labelled with digoxigenin using a digoxigenin RNA labelling kit (Roche Molecular Biochemicals, Tokyo, Japan) according to the manufacturer's instructions. Tissue sections were deparaffinised in xylene and ethanol and treated with $0.2 \mathrm{M}-\mathrm{HCl}$ for $8 \mathrm{~min}, 0.1 \mathrm{M}$-triethanolamine- $\mathrm{HCl}(\mathrm{pH} 8.0)$ for $1 \mathrm{~min}$, and $0.26 \%(\mathrm{v} / \mathrm{v})$ acetic anhydride in $0.1 \mathrm{M}$-triethanolamine $(\mathrm{pH} \mathrm{8.0)}$ for $15 \mathrm{~min}$. After rinsing for $10 \mathrm{~min}$ with $2 \times$ sodium chloride and sodium citrate (SSC) buffer ( $0.03 \mathrm{M}$-sodium citrate, $0.3 \mathrm{M}-\mathrm{NaCl}, \mathrm{pH}$ 7.0), the sections were incubated with a hybridisation solution which contained digoxigenin-labelled probe $(6 \mathrm{ng} / \mu \mathrm{l})$ in hybridisation buffer $(50 \%(\mathrm{v} / \mathrm{v})$ formamide, $2 \times \mathrm{SSC}, 10 \%$ $(\mathrm{w} / \mathrm{v})$ dextran sulfate, yeast t-RNA $(1 \mu \mathrm{g} / \mu \mathrm{l})$, sonicated salmon sperm DNA $(1 \mu \mathrm{g} / \mu \mathrm{l})$ and bovine serum albumin $(1 \mu \mathrm{g} / \mu \mathrm{l}))$ at $50^{\circ} \mathrm{C}$ for $16 \mathrm{~h}$. After hybridisation, the slides were sequentially washed with $5 \times \mathrm{SSC}(0.075$ M-sodium citrate, $0.75 \mathrm{M}-\mathrm{NaCl}, \mathrm{pH} 7.0$ ) solution at $60^{\circ} \mathrm{C}$ for $10 \mathrm{~min}$, $50 \%(\mathrm{v} / \mathrm{v})$ formamide and $2 \times \mathrm{SSC}$ at $60^{\circ} \mathrm{C}$ for $30 \mathrm{~min}$, and TNE buffer ( $0.5 \mathrm{M}-\mathrm{NaCl}, 10 \mathrm{mM}$-tri(hydroxymethyl)-aminomethane (Tris)- $\mathrm{HCl}, \mathrm{pH} 7 \cdot 6$ ) at $37^{\circ} \mathrm{C}$ for $10 \mathrm{~min}$. The sections were treated with RNase A $(2 \mu \mathrm{g} / \mathrm{ml})$ in TNE buffer at $37^{\circ} \mathrm{C}$ for $30 \mathrm{~min}$, followed by washing with TNE buffer at $37^{\circ} \mathrm{C}$ for $30 \mathrm{~min}$, with $2 \times \mathrm{SSC}$ at $48^{\circ} \mathrm{C}(30 \mathrm{~min}$, twice) and $0.2 \times \mathrm{SSC}$ at $48^{\circ} \mathrm{C}(30 \mathrm{~min}$, twice). After washing with 0.1 $\mathrm{M}-$ Tris- $\mathrm{HCl}(\mathrm{pH} \mathrm{7.5)}$ at room temperature for $10 \mathrm{~min}$, the slides were incubated with a blocking buffer containing $1 \%$ (w/v) blocking reagent (Roche Molecular Biochemicals, Tokyo, Japan) in $0 \cdot 1 \mathrm{M}$-Tris- $\mathrm{HCl}(\mathrm{pH} 7 \cdot 5)$ at room temperature for $60 \mathrm{~min}$. The slides were incubated for $18 \mathrm{~h}$ at $4^{\circ} \mathrm{C}$ with a blocking buffer containing anti-digoxigenin-alkaline phosphatase and antigen-binding fragments (Fab; Roche Molecular Biochemicals, Tokyo, Japan). These slides were washed four times with $0.1 \mathrm{M}$-Tris- $\mathrm{HCl}(\mathrm{pH} \mathrm{7.5)}$ for $10 \mathrm{~min}$ and soaked in buffer containing $0.1 \mathrm{M}$-Tris, $0.1 \mathrm{M}-\mathrm{NaCl}, 0.2 \mathrm{M}-\mathrm{MgCl}_{2}$ (pH 9.5) at room temperature for $5 \mathrm{~min}$. Finally, immunoreactivity of sections was visualised by incubating for $18 \mathrm{~h}$ at $4^{\circ} \mathrm{C}$ with $450 \mu \mathrm{g}$ NBT (nitroblue tetrazolium chloride) and $175 \mu \mathrm{g}$ BCIP (5-bromo-4-chloro-3-indolyl-phosphate, 4-toluidine salt) 
solution in $1 \mathrm{ml}$ of buffer containing $0 \cdot 1 \mathrm{M}$-Tris, $0 \cdot 1 \mathrm{M}-\mathrm{NaCl}$ and $0.2 \mathrm{M}-\mathrm{MgCl}_{2}$ (pH 9.5).

\section{Statistical analysis}

Results are expressed as mean values with their standard errors. The significance of differences was determined by ANOVA followed by Tukey's multiple-range test to compare among each stage of postnatal development (Fig. 1), or Student's $t$ test to compare between two groups (Fig. 2) or Dunnett's multiple-range test to compare between CBP/p300 mRNA treated with glycerol without any fatty acids (control) and those with fatty acids (Fig. 3) as appropriate.

\section{Results}

Postnatal changes in gene expression of $C B P / p 300$ in rat jejunum

In the first experiment, the rat pups were kept with their mothers until weaning was completed. In the present study, we focused on jejunal expression of $\mathrm{CBP} / \mathrm{p} 300$ because the bulk of digestion and absorption of nutrients in the small intestine occurs in the jejunum. At the ages of 5, 13, 20, 27 and $42 \mathrm{~d}$, the jejunal total RNA was extracted and subjected to Northern blot hybridisation for CBP/p300 mRNA. $\mathrm{CBP} / \mathrm{p} 300 \mathrm{mRNA}$ levels were high during the suckling and middle of the weaning period (5-20d after birth), and reached maximal levels at $20 \mathrm{~d}$ after birth. At their peak $\mathrm{CBP} / \mathrm{p} 300$ mRNA levels were $1.5,2.4$, and 4.0 times the level seen in 5 (suckling period), 27 (end of weaning period) and $42 \mathrm{~d}$ old rats (period after weaning), respectively. The CBP/p300 mRNA level then declined to a low basal level at the end of the weaning period (at age $27 \mathrm{~d}$ ). This low level of expression was also observed at age $42 \mathrm{~d}$ (Figs. 1 (A) and (B)). In situ hybridisation analysis showed that $\mathrm{CBP} / \mathrm{p} 300 \mathrm{mRNA}$ was expressed in the entire villus

(A)

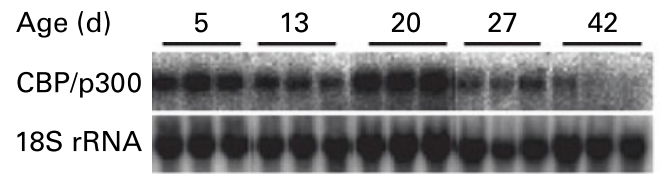

(B)

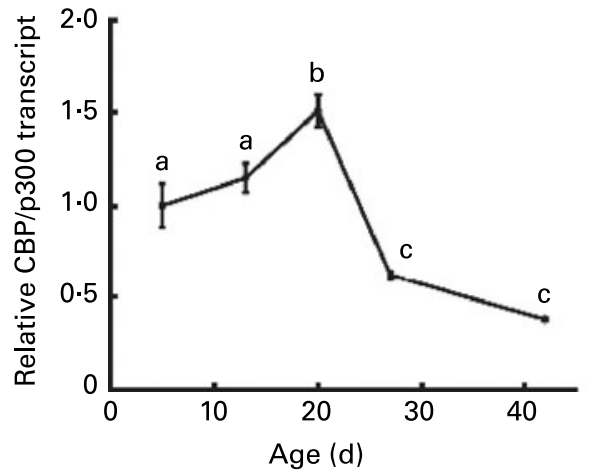

and basal membrane at age 5 and $20 \mathrm{~d}$ and its expression had clearly disappeared by age $42 \mathrm{~d}$ (Fig. 1 (C)).

\section{Dietary fat-induced CBP/p300 gene expression in the postnatal small intestine}

Suckling rats receive milk which is rich in fatty acids from their mother. To investigate whether the expression of the $\mathrm{CBP} / \mathrm{p} 300$ gene observed in the suckling-weaning period (Fig. 1) was associated with the fat intake from milk, we performed Northern blot analyses for $\mathrm{CBP} / \mathrm{p} 300 \mathrm{mRNA}$ in the rat pups that were weaned to a low- or a high-fat diet at age $17 \mathrm{~d}$. $\mathrm{CBP} / \mathrm{p} 300 \mathrm{mRNA}$ levels at ages 21 and $28 \mathrm{~d}$ in the rats fed a high-fat diet were 1.5 -fold $(P<0.05)$ and 1.6 -fold $(P<0.05)$ higher, respectively, than the corresponding mRNA levels in the rats fed a low-fat diet (Fig. 2).

\section{Expression of jejunal CBP/p300 gene in weanling rats supplemented with fatty acids}

To examine which particular fatty acids in components of milk up-regulat gene expression of $\mathrm{CBP} / \mathrm{p} 300$ in the rat postnatal small intestine, we orally administered caprylic acid, oleic acid, linoleic acid and arachidonic acid at a dose rate of $180 \mu \mathrm{mol} / \mathrm{kg} \mathrm{BW}$ to weanling rats. The CBP/p300 mRNA level was induced 3.0-fold by caprylic acid $(P<0 \cdot 01)$, 3.6fold by oleic acid $(P<0.01)$ and $2 \cdot 8$-fold by linoleic acid $(P<0.05)$. Arachidonic acid tended to enhance the CBP/ p300 mRNA level (Fig. 3) but not significantly.

\section{Discussion}

Rat pups ingest fatty acids as major nutrients from milk during the suckling-weaning period, which normally lasts until $27 \mathrm{~d}$ after birth in rats ${ }^{2,3}$. During this period, expression of many genes related to digestion and absorption increases markedly.

(C)
Day 5

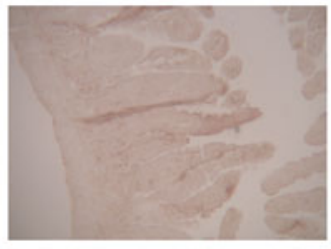

Day 42

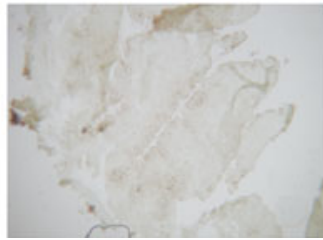

Day 20

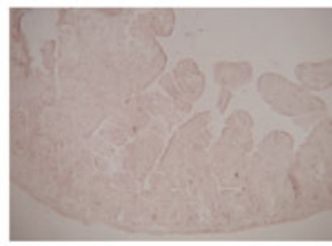

Sense probe (day 20)

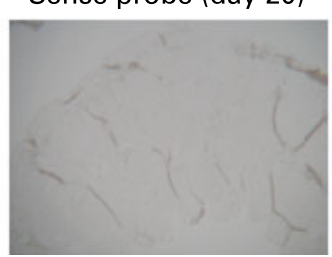

Fig. 1. Postnatal changes of cAMP-response-element-binding-protein-binding protein (CBP)/p300 mRNA level in rat jejunum. (A) Northern blotting. Total RNA $(10 \mu \mathrm{g})$ was analysed for CBP/p300 mRNA by Northern blot hybridisation. (B) mRNA levels normalised to 18S rRNA abundance. Values are means for four animals, with their standard errors represented by vertical bars. ${ }^{a, b, c}$ Values with unlike letters are significantly different from one another by Tukey's multiple range test $(P<0.05)$. (C) In situ hybridisation for CBP/p300 mRNA using digoxigenin-labelled antisense cRNA in rat jejunum at 5, 20 and $42 \mathrm{~d}$ after birth. Sense cRNA (lower right) was used to show that unrelated cRNA did not hybridise in tissue. All pictures were taken at 100-fold magnitude. 


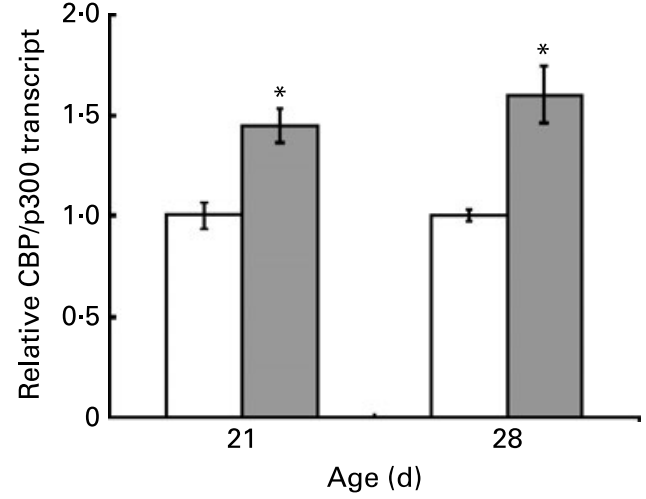

Fig. 2. Effects of dietary fat on the expression of jejunal cAMP-responseelement-binding-protein-binding protein (CBP)/p300 genes during the weaning period. Rat pups ( $17 \mathrm{~d}$ old) were removed from their mothers and they received a high-fat ( $\square$ ) or a low-fat $(\square)$ diet for 4 and $11 \mathrm{~d}$. Each mRNA level was normalised to 18S rRNA abundance. Values are means for four animals, with their standard errors represented by vertical bars. ${ }^{*}$ Mean value is significantly different from that for the low-fat-fed control rats $(P<0.05)$.

This is especially so for genes associated with fatty acid absorption and induced in the small intestine. During this period intestinal morphology also changes dramatically $5,7,8,13,14,31$. It is thought that fatty acids in milk play an important role in stimulating gene expression as well as intestinal maturation and differentiation during this period. Recent studies indicate that chromatin remodelling factors such as coactivators which have histone acetyltransferase activity regulate expression of genes involved with the cell cycle and differentiation ${ }^{22}$. In particular, $\mathrm{CBP} / \mathrm{p} 300$, which is a

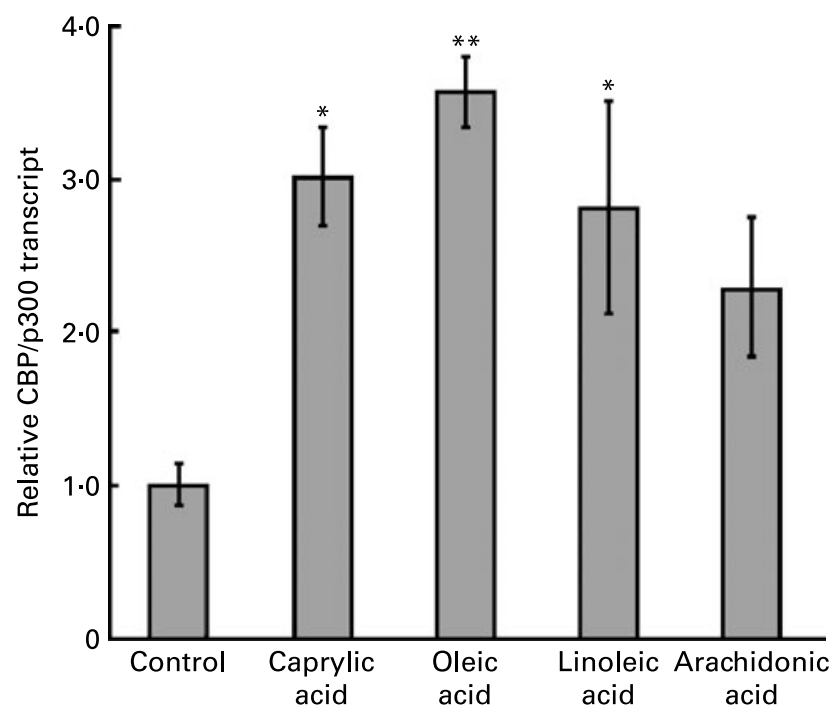

Fig. 3. Effects of fatty acids in milk on mRNA level of cAMP-responseelement-binding-protein-binding protein (CBP)/p300 in the jejunum of weanling rats. Total RNA $(10 \mu \mathrm{g})$ was analysed for CBP/p300 by Northern blot hybridisation. Northern blots of RNA were derived from the jejunum of $30 \mathrm{~d}$ old rats that had been orally administered with caprylic acid, oleic acid, linoleic acid or arachidonic acid in $20 \%$ glycerol or vehicle (control) at ages 27 , 28, 29 and $30 \mathrm{~d}$. Each mRNA level was normalised to 18S rRNA abundance. Values are means for four animals, with their standard errors represented by vertical bars. Mean value is significantly different from that for the control rats: ${ }^{*} P<0.05,{ }^{* *} P<0.01$. major coactivator, is expressed in the small intestine and transmits fatty acid signalling through PPAR $\alpha^{16,23}$. CBP/p300 has multiple functions in the cell cycle, in differentiation, in cancer and in transcription. One major role for $\mathrm{CBP} / \mathrm{p} 300$ involves activation of transcription by acetylating histones and binding to transcriptional factors including PPAR on the target genes ${ }^{32}$. CBP/p300 also transmits signals of many transcriptional factors for small-intestinal gene expression such as $\mathrm{Cdx}-2^{25}, \mathrm{HNF}-1^{26}, \mathrm{HNF}-4^{27}, \mathrm{RXR}^{28}$ and $\mathrm{RAR}^{28}$. It is probable that $\mathrm{CBP} / \mathrm{p} 300$ regulates intestinal gene expression as well as differentiation stimulated by fatty acids in milk during the suckling-weaning period.

In the present study, we focused on changes in expression of the CBP/p300 gene during the postnatal period. By measuring mRNA levels at the ages of 5, 13, 20, 27 and $42 \mathrm{~d}$, we have shown in the present study that the $\mathrm{CBP} / \mathrm{p} 300$ mRNA in the small intestine is highly expressed in the jejunum during the period from suckling to the middle of weaning (days 520) compared with levels of expression at the end of weaning (day 27) and after weaning (day 42) (Figs. 1 (A) and (B)). It should be noted that $\mathrm{CBP} / \mathrm{p} 300$ protein levels in the jejunum during the suckling-weaning period were not measured in the present study. Further work is needed to investigate the jejunal $\mathrm{CBP} / \mathrm{p} 300$ protein level during the suckling-weaning period. In situ hybridisation showed that CBP/p300 mRNA level was high at suckling (age $5 \mathrm{~d}$ ) and in the middle of the weaning period (age $20 \mathrm{~d}$ ), and its expression was undetectable after weaning (age 42 d) (Fig. 1 (C)). Considering that CBP/ p300 mRNA in adult rat jejunum is relatively rich compared with other tissues such as liver, heart, skeletal muscle and colon $^{16}$, the mRNA levels in the jejunum during the suckling-weaning period are speculated to be physiologically abundant. These results indicate that expression of the CBP/ p300 gene during the postnatal period is associated with dietary fat intake from milk.

To investigate whether dietary fatty acids are able to modulate $\mathrm{CBP} / \mathrm{p} 300$ gene expression during this period, we removed rat pups from their mothers at age $17 \mathrm{~d}$ to wean them to either a low- or a high-fat diet. In the rats fed the high-fat diet, CBP/p300 mRNA level was enhanced (Fig. 2). The milk produced by rats is rich in fatty acids, especially the medium-chain fatty acids, $n-6$ fatty acids and n-9 fatty acids $^{33}$. Several studies have suggested that medium-chain fatty acids and unsaturated fatty acids are important for development of the infant ${ }^{34,35}$. Thus, we focused in the present study on these fatty acids, although other fatty acids such as long-chain SFA are also present in milk. As shown in Fig. 3, we examined expression of $\mathrm{CBP} / \mathrm{p} 300$ genes following oral administration of a range of fatty acids, namely the mediumchain fatty acid caprylic acid, the $n-9$ fatty acid oleic acid, and the $n$-6 PUFA linoleic acid and arachidonic acid, all of which are components of the milk of weaning rats. In the present study, we chose a dietary fat inclusion level of $24.7 \%(\mathrm{w} / \mathrm{w})$ in the diet described in Fig. 2, and fatty acid concentrations in a $20 \%$ glycerol solution of $180 \mu \mathrm{mol} / \mathrm{kg}$ $\mathrm{BW}$, which corresponded to concentrations in solution in the range of $2.5-6 \%(\mathrm{w} / \mathrm{w})$ fatty acids (Fig. 3). Considering that the percentage milk fat $(\mathrm{w} / \mathrm{w})$ in rodents is about $20 \%{ }^{36}$, these concentrations of dietary fat and fatty acids are physiologically realistic. Interestingly, CBP/p300 was significantly induced by caprylic acid, oleic acid and linoleic acid 
(Fig. 3). Additionally, arachidonic acid tended to induce CBP/ p300 expression. These results suggest that fatty acids in milk may be one of the primary nutritional factors that maintain an enhanced level of expression of the $\mathrm{CBP} / \mathrm{p} 300$ gene during the suckling-weaning period, although other factors such as thyroid hormone and glucocorticoid hormone, which are known to increase in serum during this period ${ }^{1-3}$, may also contribute to regulation of $\mathrm{CBP} / \mathrm{p} 300$ expression.

The molecular mechanism of $\mathrm{CBP} / \mathrm{p} 300$ function in the small intestine during the suckling-weaning period is unknown. $\mathrm{CBP} / \mathrm{p} 300$ strongly regulates $\mathrm{PPAR} \alpha$ signalling in the small intestine ${ }^{16}$. In the postnatal small intestine, PPAR $\alpha$ is highly expressed and mediates the expression of smallintestinal genes such as L-FABP and I-FABP, which are known to be target genes of PPAR $\alpha^{8}$. Moreover, both L-FABP and the CRBP II gene, which is a putative target gene of PPAR $\alpha$, were induced by caprylic acid and oleic acid in weanling rats $^{38}$. Thus, the expression change of $\mathrm{CBP} / \mathrm{p} 300$ gene during postnatal development might regulate the transactivity of PPAR $\alpha$. CBP/p300 also mediates the signalling of other intestinal transcriptional factors such as $\mathrm{Cdx}-2^{37}, \mathrm{HNF}-1^{26}$, thyroid hormone receptor (TR) $\alpha-1^{39}$, retinoid $\mathrm{X}$ receptor ${ }^{28}$ and $\mathrm{RAR}^{28}$. Gene expression of SI a putative target gene for Cdx-2 and HNF-1, also increases during the suckling-weaning transitional period, when $\mathrm{Cdx}-2$ and HNF-1 expressions are high ${ }^{6,9}$. The present results also indicate that TR $\alpha-1$ is not only highly expressed during the suckling-weaning transitional period, but also regulates GLUT5 gene expression during this period ${ }^{6}$. It remains to be resolved whether $\mathrm{CBP} / \mathrm{p} 300$ regulates intestinal gene expression by transmitting the signalling of PPAR as well as these intestinal transcriptional factors during postnatal development.

In conclusion, the results of the present study suggest that expression of small-intestinal $\mathrm{CBP} / \mathrm{p} 300$ during postnatal development is regulated by fatty acids derived from milk. The results of the present study are the first evidence that dietary fatty acids enhance expression of the $\mathrm{CBP} / \mathrm{p} 300$ gene. Further work should investigate whether intestinal expression of genes during the suckling-weaning period is regulated by $\mathrm{CBP} / \mathrm{p} 300$ as well as considering the differences in expression and function between CBP and p300 in the postnatal small intestine.

\section{Acknowledgements}

The present study was supported by a Grant-in-Aid for Scientific Research from the Ministry of Education, Science, Sports and Culture of Japan $(18590220,18790171)$ and the Center of Excellence programme in the 21st century from the Ministry of Education, Science, Sports and Culture of Japan.

\section{References}

1. Koldovsky O (1984) Development of human gastrointestinal functions: interaction of changes in diet composition, hormonal maturation, and fetal genetic programming. J Am Coll Nutr 3, $131-138$.

2. Anonymous (1985) Response of the gastrointestinal tract to premature weaning in experimental animals. Pediatrics 75, 199-206.
3. Koldovsky O, Dobiasova M, Hahn P, Kolinska J, Kraml J \& Pacha J (1995) Development of gastrointestinal functions. Physiol Res 44, 341-348.

4. Henning SJ (1982) Role of milk-borne factors in weaning and intestinal development. Biol Neonate 41, 265-272.

5. Krasinski SD, Estrada G, Yeh KY, Yeh M, Traber PG, Rings EH, Buller HA, Verhave M, Montgomery RK \& Grand RJ (1994) Transcriptional regulation of intestinal hydrolase biosynthesis during postnatal development in rats. Am J Physiol 267, G584-G594.

6. Mochizuki K, Yagi E, Sakaguchi N, Mochizuki H, Takabe S, Kuranuki S, Suzuki T, Shimada M \& Goda T (2007) The critical period for thyroid hormone responsiveness through thyroid hormone receptor isoform $\alpha$ in the postnatal small intestine. Biochim Biophys Acta 1770, 609-616.

7. Ogura Y, Suruga K, Takase S \& Goda T (2005) Developmental changes of the expression of the genes regulated by retinoic acid in the small intestine of rats. Life Sci 77, 2804-2813.

8. Mochizuki K, Suruga K, Yagi E, Takase S \& Goda T (2001) The expression of PPAR-associated genes is modulated through postnatal development of PPAR subtypes in the small intestine. Biochim Biophys Acta 1531, 68-76.

9. Kuranuki S, Mochizuki K, Tanaka T \& Goda T (2007) The possible roles of homeobox protein, $\mathrm{Cdx}-2$ for the expression of LPH gene during postnatal development. Life Sci 80 , 795-799.

10. Evans RM (2005) The nuclear receptor superfamily: a rosetta stone for physiology. Mol Endocrinol 19, 1429-1438.

11. Jump DB \& Clarke SD (1999) Regulation of gene expression by dietary fat. Annu Rev Nutr 19, 63-90.

12. Gottlicher M, Widmark E, Li Q \& Gustafsson JA (1992) Fatty acids activate a chimera of the clofibric acid-activated receptor and the glucocorticoid receptor. Proc Natl Acad Sci U S A 89, 4653-4657.

13. Gordon JI, Elshourbagy N, Lowe JB, Liao WS, Alpers DH \& Taylor JM (1985) Tissue specific expression and developmental regulation of two genes coding for rat fatty acid binding proteins. J Biol Chem 260, 1995-1998.

14. Rubin DC, Ong DE \& Gordon JI (1989) Cellular differentiation in the emerging fetal rat small intestinal epithelium: mosaic patterns of gene expression. Proc Natl Acad Sci U S A 86, $1278-1282$.

15. Quick TC \& Ong DE (1989) Levels of cellular retinol-binding proteins in the small intestine of rats during pregnancy and lactation. J Lipid Res 30, 1049-1054.

16. Mochizuki K, Suruga K, Sakaguchi N, Takase S \& Goda T (2002) Major intestinal coactivator p300 strongly activates peroxisome proliferator-activated receptor in intestinal cell line, Caco-2. Gene 291, 271-277.

17. Escher P, Braissant O, Basu-Modak S, Michalik L, Wahli W \& Desvergne B (2001) Rat PPARs: quantitative analysis in adult rat tissues and regulation in fasting and refeeding. Endocrinology 142, 4195-4202.

18. Poirier H, Niot I, Degrace P, Monnot MC, Bernard A \& Besnard P (1997) Fatty acid regulation of fatty acid-binding protein expression in the small intestine. Am J Physiol 273, G289-G295.

19. Mochizuki K, Suruga K, Kitagawa M, Takase S \& Goda T (2001) Modulation of the expression of peroxisome proliferator-activated receptor-dependent genes through disproportional expression of two subtypes in the small intestine. Arch Biochem Biophys 389, 41-48.

20. Suruga K, Mochizuki K, Kitagawa M, Goda T, Horie N, Takeishi K \& Takase S (1999) Transcriptional regulation of cellular retinol-binding protein, type II gene expression in small intestine by dietary fat. Arch Biochem Biophys 362, $159-166$. 
21. Soutoglou E \& Talianidis I (2002) Coordination of PIC assembly and chromatin remodeling during differentiation-induced gene activation. Science 295, 1901-1904.

22. Aranda A \& Pascual A (2001) Nuclear hormone receptors and gene expression. Physiol Rev 81, 1269-1304.

23. Dowell P, Peterson VJ, Zabriskie TM \& Leid M (1997) Ligand-induced peroxisome proliferator-activated receptor $\alpha$ conformational change. J Biol Chem 272, 2013-2020.

24. Shikama N, Lutz W, Kretzschmar R, Sauter N, Roth JF, Marino S, Wittwer J, Scheidweiler A \& Eckner R (2003) Essential function of p300 acetyltransferase activity in heart, lung and small intestine formation. EMBO $J \mathbf{2 2}$, 5175-5185.

25. Hussain MA \& Habener JF (1999) Glucagon gene transcription activation mediated by synergistic interactions of pax- 6 and cdx-2 with the p300 co-activator. $J$ Biol Chem 274, 28950-28957.

26. Soutoglou E, Papafotiou G, Katrakili N \& Talianidis I (2000) Transcriptional activation by hepatocyte nuclear factor-1 requires synergism between multiple coactivator proteins. J Biol Chem 275, 12515-12520.

27. Soutoglou E, Viollet B, Vaxillaire M, Yaniv M, Pontoglio M \& Talianidis I (2001) Transcription factor-dependent regulation of $\mathrm{CBP}$ and P/CAF histone acetyltransferase activity. EMBO J 20, 1984-1992.

28. Blanco JC, Minucci S, Lu J, Yang XJ, Walker KK, Chen H, Evans RM, Nakatani Y \& Ozato K (1998) The histone acetylase PCAF is a nuclear receptor coactivator. Genes Dev 12, 1638-1651.

29. Goda T, Yasutake H \& Takase S (1994) Dietary fat regulates cellular retinol-binding protein II gene expression in rat jejunum. Biochim Biophys Acta 1200, 34-40.

30. Chomczynski P \& Sacchi N (1987) Single-step method of RNA isolation by acid guanidinium thiocyanate-phenol-chloroform extraction. Anal Biochem 162, 156-159.
31. Green RP, Birkenmeier EH, Beamer WG, Maltais LJ \& Gordon JI (1988) The hypothyroid (hyt/hyt) mouse: a model system for studying the effects of thyroid hormone on developmental changes in gene expression. Proc Natl Acad Sci U S A 85, 5592-5596.

32. Kalkhoven E (2004) CBP and p300: HATs for different occasions. Biochem Pharmacol 68, 1145-1155.

33. Mills DE, Ward RP \& Huang YS (1990) Fatty acid composition of milk from genetically normotensive and hypertensive rats. J Nutr 120, 431-435.

34. Hamosh M (1987) Lipid metabolism in premature infants. Biol Neonate, 52, Suppl. 1, 50-64.

35. Muskiet FA, van Goor SA, Kuipers RS, Velzing-Aarts FV, Smit EN, Bouwstra H, Dijck-Brouwer DA, Boersma ER \& HaddersAlgra M (2006) Long-chain polyunsaturated fatty acids in maternal and infant nutrition. Prostaglandins Leukot Essent Fatty Acids 75, 135-144.

36. Teter BB, Sampugna J \& Keeney M (1990) Milk fat depression in $\mathrm{C} 57 \mathrm{~B} 1 / 6 \mathrm{~J}$ mice consuming partially hydrogenated fat. $J$ Nutr 120, 818-824.

37. Lorentz O, Suh ER, Taylor JK, Boudreau F \& Traber PG (1999) CREB-binding [corrected] protein interacts with the homeodomain protein $\mathrm{Cdx} 2$ and enhances transcriptional activity. J Biol Chem 274, 7196-7199.

38. Mochizuki K, Mochizuki H, Kawai H, Ogura Y, Shimada M, Takase S \& Goda T (2007) Possible role of fatty acids in milk as the regulator of the expression of cytosolic binding proteins for fatty acids and vitamin A through PPARalpha in developing rats. J Nutr Sci Vitaminol (in press).

39. De Luca A, Severino A, De Paolis P, Cottone G, De Luca L, De Falco M, Porcellini A, Volpe M \& Condorelli G (2003) p300/ cAMP-response-element-binding-protein ('CREB')-binding protein (CBP) modulates co-operation between myocyte enhancer factor 2A (MEF2A) and thyroid hormone receptor-retinoid $\mathrm{X}$ receptor. Biochem J 369, 477-484. 